\title{
TÜRKÇEYİ YABANCI DİL OLARAK ÖĞRENENLERIN YAZMA KAYGILARI
}

\author{
Sedat MADEN* \\ Ömür DİNCEL ${ }^{* *}$ \\ Aslı MADEN ${ }^{* * *}$
}

$\ddot{\mathbf{O z}}$

Temel dil becerilerinden birisi olan yazma becerisinin önemini "Söz uçar, yazı kalır." atasözü en güzel şekilde ifade etmektedir. Yabancı uyruklu öğrencilere yazma becerisi kazandırma söz konusu olduğunda, bu becerinin hedef dilde planlanması ve alışkanlık hâline dönüştürülmesi zahmetli ve zor olmaktadır. Bu çalışmanın amacı, ülkemizde öğrenim gören yabancı uyruklu üniversite öğrencilerinin yazma kaygılarını cinsiyet, uyruk, ögrenim gördüğ̈̈ fakülte/yüksekokul, bildiği diğer yabancı diller, Türkçeyi ögrenme amacı, Türkçe düzeyi, okuma alışkanlı̆̆ gibi değiş̧kenler 1şı̆̆ında ele almak ve bu değişkenler açısıından öğrencilerin yazma kaygıları arasında anlamlı fark olup olmadığını tespit etmektir. Araştırma, 2014-2015 eğitim-öğretim yılında Giresun Üniversitesinin değişik bölümlerinde öğrenim gören 172 yabanc1 uyruklu öğrenci üzerinde yapılmıştır. Çalışma, tarama modeliyle gerçekleştirilmiştir. Verilerin elde edilmesinde araştırmacılar tarafından yabancı uyruklu öğrencilerin yazma kaygılarının tespitine yönelik geliştirilen "Yazma Kaygısı Ölçeği”" kullanılmıştır. Yabancı uyruklu öğrencilerin Türkçe yazarken çoğunlukla kaygılandıkları, kaygı düzeylerinin uyruk, alfabe farkı, okuma alışkanlığı gibi etkenlere bağlı olarak farklılaştığı tespit edilmiştir.

\section{Anahtar Sözcükler: Yabancı uyruklu öğrenciler, Türkçe öğretimi, yazma becerisi, yazma kaygisi. \\ WRITING ANXIETIES OF PEOPLE WHO LEARN TURKISH AS A FOREIGN LANGUAGE}

\begin{abstract}
The Latin proverb "verba volant scripta manent" meaning "spoken words fly away, written words remain" best shows the importance of writing skill which is one of the basic language skills. When it comes to writing skills of foreign students, making plans in target language in regards to this skill and develop a habit of writing are more difficult and exhausting compared to those for native speakers of a language. The aim of the study is to investigate writing anxieties of foreign students in Turkish universities according to such variables; "their gender, nationality, academic department, other foreign language they speak, their aim of learning Turkish, their level of Turkish and their reading habits and to explore whether there are any significant differences between the students' writing anxieties with respect to these variables. For the study, 172 foreign students who study in different departments of Giresun University in 2014-2015 education year participated. The study is a survey type research study. The data was gathered through "Writing Anxiety Scale" which was created by the researchers in order to determine writing anxieties of foreign students. It was found that foreign
\end{abstract}

\footnotetext{
* Doç. Dr.; Giresun Üniversitesi, Eğitim Fak. Türkçe Eğitimi Bölümü, sedd52@ gmail.com.

*** Okt.; Giresun Üniversitesi, TÖMER, dincel_55@hotmail.com.

*** Okt.; Giresun Üniversitesi, Eğitim Fak. Türkçe Eğitimi Bölümü, asmaden25@ gmail.com.
} 
students usually felt anxiety about writing in Turkish and their level of anxiety differentiated according to such variables; nationality, alphabet of their native language and their reading habits.

Keywords: Foreign students, teaching Turkish, writing skill, writing anxiety.

\section{Giriş:}

Değişen dünya düzeni insanların yaşama alışkanlıklarını ve gerekliliklerini, biyolojik, psikolojik ve sosyal ihtiyaçlarını ve bunların tedarik edilme yollarını, bunlarla birlikte ihtiyaçları isteme ve edinme yollarını yani iletişim yollarını değiştirmekte, teknoloji ve hız endeksli bir boyuta taşımaktadır. Bu durum, toplum içinde çağın özelliklerine sahip, kültürlü ve iletişim gücü yüksek insanlara olan ihtiyacı ortaya çıkarmıştır.

İnsanoğlunun sosyal yönü, diğer insanlarla iletişim kurmasını, bilgi alışverişinde bulunmasını, yazılı ve sözlü iletişim becerisine sahip olmasını zorunlu kılmaktadır. Çünkü kültür yazılı ya da sözlü olarak geleceğe taşınabilmektedir. Sözlü olarak geleceğe taşınan kültür zamanla tarihe yenik düşerken, yazılı olarak geleceğe taşınan kültürler uzun yıllar varlığını sürdürebilmektedir. Buradan yazının tarihe 1şık tutan yönü ve yazma eyleminin önemi rahatlıkla anlaşılabilmektedir. Buna göre yazı, dili somutlaştıran ve dile canlılık kazandıran bir araç olarak tanımlanabilir.

Yazılı anlatım becerisi iletişim araçlarının en etkili olanıdır (Ungan, 2007: 462). Çünkü insanlar okul, iş yeri, aile $v b$. sosyal hayatın her alanında yazma becerisine gereksinim duymaktadırlar. İlgili araştırmalar incelendiğinde, yazma üzerine birçok farklı tanımın yapıldığı göze çarpmaktadır. Göçer (2010: 178) yazmayı; herhangi bir konuda duygu, hayal ya da özgün fikirleri belli bir düzen ve bütünlük içinde yazıya geçirme işi olarak tanımlamıştır. Carter $v d$.'ne (2002: 246) göre yazma, bilginin elde edilmesi ve bilginin ifade edilmesi ile ilgili süreçlerden oluşan bir beceridir. Nunan'a (2003: 88) göre yazma ise; düşüncelerin ortaya çıkarılıp nasıl ifade edileceğinin belirtilmesi, bunların cümleler ve paragraflar hâlinde okuyucuya sunulmasıdır. Demirel'e göre (2002: 100) yazma becerisi dört temel dil becerisi zincirinin son halkası olduğundan yazma becerisini mekanik olarak değil, eleştirel bir düşünme süreci olarak algılamak ve bilmek gerekir. Buradan hareketle yazma becerisinin geliştirilebilmesi bireyin diğer dil becerileri yardımıyla kendini geliştirmesine ve yazmaya hazır hâle getirmesine bağlıdır denilebilir.

Yazı yazmak, belli bir birikim ve bilgi isteyen zor bir uğraştır (Yalçın, 1998: 149). Çünkü yazma becerisi dil becerisi dışında metin türleri ve tümceler arasında bütünlük oluşturan zaman açısından bir sıralama, neden-sonuç, süreç gibi mantıksal bilgiye dayanan ilişkilerin yanı sıra akıl yürütme, anlamsal ağların canlandırılması, analiz, sentez, planlama gibi kontrol 
merkezi bellek olan bir dizi zihinsel strateji içerir (Yalçı, 1997: 381). Diğer dil becerileri ile arasında güçlü bir ilişki bulunan yazma becerisi ancak diğer dil becerilerinin kazanılması durumunda olumlu yönde gelişecektir. Çünkü okuyan, dinleyen ve konuşan bireylerin bu etkinlikler sayesinde ufukları açılacak, hayal dünyaları gelişecek ve bu sayede yazma konusunda sıkıntı yaşamayacaklardır. Bu nitelik, yazma eyleminin bir anda ve kısa sürede gerçekleştirilebilecek bir iş olmadığını göstermektedir. Yazma eylemine başlamadan önce ayrıca bir dizi hazırlık yapmak (konu, amaç, tür seçimi $v b$.) ve yazılacak metni ya da olayı planlamak gerekmektedir. Yazma, temel dil becerilerinin eğitiminde değerlendirme yapma ve dönüt düzeltme işlevi üstlendiğinden doğru ve etkili yazılı anlatım becerisi kazandırmak dil eğitimi sürecinde hassasiyet gösterilmesi gereken bir konudur.

Yazma eylemi hem öğrenciler hem öğretmenler hem de tüm bireyler için güçlükleri olan bir süreçtir. $\mathrm{Bu}$ durum, yazma sürecinde yaşanan psikolojik, dil bilgisel ve bilişsel sorunlardan kaynaklanmaktadır (Öztürk, 2012: 60). Yazma çalışmalarının zor bir uğraş olarak görülmesinin bir başka sebebini de okullardaki tekdüze yazma çalışmalarında ve öğrenciye konu özgürlüğü tanımayan sistemde aramak yerinde ve isabetli olacaktır. Çünkü okullardaki kompozisyon dersleri yıllarca öğretmenin belirlediği bir konu üzerinden (atasözü, özdeyiş $v b$.) yürütülmüştür. $\mathrm{Bu}$ da öğrencileri yazma konusunda isteksizleştirmiş, yazmayı bireylerin korktuğu bir eylem hâline sokmuş̧tur. Bu nedenle yazma çalışmalarında çağdaş eğitim anlayışının gereği olarak öğrencilere konu özgürlüğü tanınmalıdır. Maksat sadece ölçmek olmamalı, öğrencileri yazma etkinliklerine karşı yüreklendirmek, isteklendirmek de olmalıdır. Ancak bu şekilde bireylerin yazmaya karşı oluşan olumsuz tabuları kırılabilir. Göçer’e (2010: 182) göre bireylerin yetkin ve başarılı bir şekilde yazılı anlatım sağlayabilmeleri için; bilgi birikimi, kültürel zenginlik, hayat tecrübesi, dili etkin ve doğru bir şekilde kullanabilme, yazma konusunda teknik bilgiye sahip olma, olaylara farklı bakış açılarından bakarak sebep-sonuç ilişkisi kurabilme, belirli ölçütler doğrultusunda farklı olay ve düşünceleri analiz edip değerlendirebilmeleri gerekir.

\section{Yabancı Dil Eğitiminde Yazma Becerisi ve Yazma Kaygısı}

Ekonomik, siyasal, sosyal ve kültürel alanlarda yaşanan hızlı gelişmeler neticesinde küreselleşen dünyamızda toplumlar arasındaki sınırlar kalkmış ve kültürel yakınlaşmalar artmıştır. Buna paralel olarak da küreselleşen dünyayla birlikte insanların ana dillerinin yanında başka dilleri de bilmeleri bir ihtiyaç olarak görülmüştür. Başka bir ifade ile "bireylere göre değişen özel amaçlar, farklı kültürlere duyulan ilgi, toplum içerisinde sürekli veya geçici olarak yaşamanın doğurduğu bir gereklilik, mesleki yaşam içerisinde ilerleme isteği”" (Aydın ve Zengin, 2008: 82) yabancı dil öğrenmedeki etkenler olarak ifade edilebilir. Bir dilin, o dilin ana 
dili olarak konuşulduğu ülkede daha kolay ve nitelikli şekilde öğrenilebileceği gerçeği bireylerin farklı ülkelere dil öğrenmek için gitmelerine neden olmaktadır. Türkiye'nin sahip olduğu kültürel özellikler, doğal güzellikler ve eğitim kalitesindeki artış yabancı öğrenciler için Türkiye'yi bir cazibe merkezi hâline getirmiştir.

Türkiye'de yabancı dil öğretimi gerek üniversiteler bünyesinde gerekse özel teşebbüslerce açılan dil öğretim merkezlerinde yapılmaktadır. Buralardaki dil öğretimi, Avrupa dil portfolyosu ölçütlerinde ve dört temel dil becerisini (okuma, konuşma, dinleme, yazma) merkeze alacak şekilde yürütülmektedir.

Bireylerin bir dile tam anlamıyla hâkim olabilmesi anlama ve anlatmaya dayalı temel dil becerilerini etkin bir şekilde kullanabilmesi ile değerlendirilir (Karatay, 2011: 21). Bu dil becerilerinden okuma, konuşma ve dinleme formel ortamlar dışında da geliştirilebilecekken yazma becerisinin geliştirilmesi formel ortamlarda sistemli ve etkili bir öğretim sürecini gerekli kılmaktadır. Zira farklı uyruklara mensup öğrencilerin dil öğreniminde yazma becerilerini geliştirebilmeleri için öğrenme ortamında farklı yöntem ve tekniklerin uygulanması öğretim sürecinin verimliliği adına çok faydalı olacaktır. Zira yabancı dil olarak Türkçe öğrenenlerin "sınıf içi veya sınıf dışında yazmalarını gerektirecek birçok sebep vardır" (Harmer, 2007: 112). İnternet ortamındaki yazışma, paylaşım, elektronik posta, telefon mesajı, başvuru formu, not alma, şikâyet mektubu, alışveriş listesi (Harmer, 2004: 12) ve günlük hayatta karşılaşılan bir dizi durum yazma ihtiyacını gerekli kılan sebepler arasında sayılabilir. Bununla birlikte Türkçenin yabancı dil olarak öğretimi sürecinde de yabanc1 uyruklu öğrencilerin öğrenme alanlarına göre değişkenlik gösteren birtakım problemler yaşadıkları ilgili alanyazında ortaya konmuştur (Açık, 2008; Alyılmaz, 2010; Karababa, 2009; Subaşı, 2010; Er, Biçer ve Bozkırlı, 2012; Şengül, 2014). İlgili alanyazından hareketle, yabancı dil olarak Türkçe öğretiminde sıklıkla karşılaşılan ve yazma becerisinin öğretiminde de etkili olan problemler aşağıdaki şekilde sıralanabilir:

$\checkmark$ Alfabe farklılı̆̆ından kaynaklanan zorluklar

$\checkmark$ Kısa sürede iletişim kurma ihtiyacı

$\checkmark$ Yazılı anlatımda karşılaşılan problemler

$\checkmark$ Müfredat eksikliğinden kaynaklı problemler

$\checkmark$ Uzman öğretici eksikliği

$\checkmark$ Ders materyalleri açısından yaşanan yetersizlikler

$\checkmark$ Türkçe dil özelliklerinden kaynaklı sorunlar 
$\checkmark$ Başvuru ve uygulamaya yönelik kaynakların yetersizliği

$\checkmark$ Kullanılan yöntem-tekniklerle ilgili sorunlar

$\checkmark \quad$ İlgili kurumlar arasındaki koordinasyon eksikliği

$\checkmark$ Eğitim-öğretim ortamlarındaki eksiklikler

$\checkmark$ Yabancı uyruklu öğrencilerin farklı değişkenlerden kaynaklı uyum, anlama, okuma, konuşma ve yazma becerilerine yönelik problemler

Yaşanan eksiklik ve sorunlar, öğrenme alanlarına yönelik dil kullanımında yabancıların yeterli başarıyı sergileyememelerine sebep olmaktadır. Diğer bir deyişle, yabancı uyruklu öğrenciler ana dil, alfabe, öğretmen, müfredat, materyal ve yöntem-tekniklerden kaynaklanan eksikliklerden hareketle gereken bilişsel ve duyuşsal yeterliliği gösterememektedir. Bu durum, ana dili ve yabanc1 dil öğretim sürecinde, öğrenci güdülenmesinin, tutumunun, ilgisinin ve öğrenme düzeyinin istenen seviyeye ulaşmasını engellemektedir.

Yabancı dil olarak Türkçenin öğretiminde, yazma becerisini istenilen düzeyde geliştirebilmek için bazı hususları göz önünde bulundurmak gerekir:

$\checkmark$ Yabancı dilde yazma eğitimi verebilmek için hitap edilen hedef kitlenin özellikleri (yaş, ana dili ve kültür yapısı vb.) göz önünde bulundurulmalıdır. Çünkü Arabistanlı ve Pakistanlı olan bireylerin dil özellikleri birbirinden farklıdır.

$\checkmark$ Rehberlik eden kişi hedef kitleyi tanımalı ve olumsuz aktarımların önüne geçmelidir. Hedef kitlenin ihtiyaç ve özelliklerine göre iletişim, öğretim tarzı, yöntem, stratejileri belirlenmelidir.

$\checkmark$ Bireylerin ana dilinin cümle yapısı göz önünde bulundurulmalıdır. Örneğin, İngilizcede söz dizimi özne+eylem+nesne şeklindeyken; Türkçede bu yapı özne+nesne+yüklem şeklindedir.

$\checkmark$ Yabancı dilde yazma eğitimi için sürekli ve planlı çalışmalar yapılmalıdır.

Yabancı dilde yazma eğitimi veren kişi yazmanın her aşamasında kişiye rehberlik etmelidir. Öğrencinin bilişsel gelişimi ile birlikte duyuşsal gelişimimi de desteklenmelidir.

$\checkmark$ Yabancı dilde yazma çalışmaları, farklı metin türlerinde çeşitli anlatım yollarından yararlanılarak yürütülebilir. Anlatım yolları seviyelere göre şu şekildedir: Başlangıç seviyesinde olan bir kişi betimlemelerin ilk aşamasındadır, fikirlerini düzenlemede ve genişletmede eksiklikler bulunur. İleri seviyede bulunanlar, başlangıç seviyesindeki öğrencilerden daha rahat bir biçimde betimlemeyi kullanabilirler. Son olarak, üst seviyedekiler açılama ve tartışma yollarını da kullanabilirler (Way, Joiner ve Seaman, 2000: 172'den aktaran Tiryaki, 2013: 39). 
Dil becerilerinin kazanılıp geliştirilmesinde bireylerin sahip oldukları heyecan, sevinç, korku, kaygı $v b$. ruh hâlleri başarıyı iyi ya da kötü yönde etkilemektedir. Başarı üzerinde etkili olan bağımsız değişkenlerden birisi de kaygıdır. Kaygı, nedeni bilinmeyen tehlike, talihsizlik, korku ya da bekleyişin yarattığ tedirginlik, akıldışı korku, endişe, bunaltı olarak tanımlanmaktadır (Bakırcıoğlu, 2012: 502). Türk Dil Kurumu (TDK, 2005: 1115) sözlüğünde kayg1; "üzüntü, endişe duyulan düşünce, tasa” olarak tanımlanmaktadır. Scovel (1978) ise kaygıyı genel anlamda tehdit unsuru içeren bir durum karşısında birey tarafindan algılanan huzursuzluk ya da korku duygusu olarak tanımlamaktadır. Kaygı bireylerde farklı şekillerde ortaya çıkabilir: 1. Geçici kaygı 2. Sürekli kaygı. Geçici kaygı, o an için karşılanamayan bir isteğin varlığıyla ortaya çıkar ve istek karşılandığında ortadan kalkar. Sürekli kaygı ise, güvenlik endişesi olan durumlardan ve bu durumun uzun süre ortadan kaldırılamayışından doğmaktadır.

Kayg1, yazma becerisini de olumsuz yönde etkileyebilmektedir. Bireylerin yazma isteklerini ve yazma etkinliklerindeki başarılarını etkileyen etkenlerden birisi de yazma kaygısıdır. Yazma kaygısı; bireyin yazdıklarının değerlendirileceği düşüncesiyle yazmaktan kaçınması durumudur (İşeri ve Ünal, 2012: 69). Yazma kaygısı yaşayan bireylerde bu ruh hâli yazma çalışmaları esnasında üzüntü, kızgınlık, korku şeklinde ya da daha ileri düzeyde, çeşitli krampların oluşması şeklinde fiziksel olarak kendini gösterir (Özbay ve Zorbaz, 2011: 34). Kaygı düzeyinin düşük veya fazla olması zararlı olup orta düzeyde ayarlanması gerekmektedir. Zira bireylerin kaygılarının az olması genel uyarılmışlık hâlinin düşük olduğunu gösterir ki bu da başarısızlığın gerekçelerinden biridir. Yine aynı şekilde kaygı düzeyinin yüksek olması da aşırı stres ve korkuyu, sonucunda da kaçınma davranışını tetiklediğinden başarısızlık için başka bir sebeptir. Dolayısıyla, yazma çalışmaları sırasında ya da her hangi bir olay esnasında kaygı duyulmalı ancak bu kaygı orta seviyede tutulmaya çalışılmalıdır. Ancak bu şekilde kaygıdan olumlu yönde faydalanabilmek mümkün olabilmektedir. Yazma kaygısı yüksek olan bireylerde birtakım olumsuz davranışlar gözlenebilmektedir. Reeves'e (1997: 38-39) göre yüksek yazma kaygısına sahip bireylerde şu davranışlar görülmektedir:

$\checkmark$ Yazma becerisini çok az gerektiren ya da hiç gerektirmeyen bir meslek seçme eğilimindedirler.

$\checkmark$ Üniversite eğitiminde, her gün yazmanın gerekli olduğu dersler ve bölümlerden kaçınma eğilimindedirler.

$\checkmark$ Sinıf dişında çok az yazarlar.

$\checkmark$ Evde, okulda ve toplum içinde yazma becerisi yönünden iyi bir örnek oluşturmazlar.

$\checkmark$ Sözel beceri testleri, okuduğunu anlama testlerinden düşük puan alırlar.

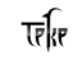

Uluslararası Türkçe Edebiyat Kültür Eğitim Dergisi Sayl: 4/2 2015 s. 748-769, TÜRKIYYE 
$\checkmark$ Yazmaya yönelik motivasyonları ister istemez düşüktür.

Türkçeyi yabancı dil olarak öğrenirken yabancıların en fazla zorlandığı alanlar arasında yazılı anlatım ilk sıralardadır (Açık, 2008; Bölükbaş, 2011; Karababa, 2009). Yabancıların Türkçe yazma becerisini öğrenirken ve sergilerken problem yaşamalarında birçok etken bulunmaktadır. Bunlara, alfabe farkı, ana dili hedef dil farkı, öğretici unsuru, güdülenme, tutumkayg1, öğretim yöntem ve materyalleri gibi çeşitli etkenler örnek verilebilir.

Yabancı dil öğrenimi sırasında bireyler, yazmanın zor bir beceri olması ile birlikte yazmaya yönelik önyargıları nedeniyle yazmaktan uzak durmaktadır. Özellikle de değerlendirilme maksatlı yazma çalışmaları bireyleri iyice strese sokmakta ve bireylerde yazma kaygısına sebep olmaktadır. Hem ana dili hem de yabancı dil öğretiminde dil öğrenme kaygısı önemli bir değişkendir. Bu bağlamda, yabancı dil olarak Türkçe öğretiminde yazma kaygı durumunun tespiti ve etkili değişkenlerin ortaya konması, öğretim faaliyetlerini düzenlemeye ve yaşanan problemleri aşmaya katkı sağlayacaktır.

\section{Araştırmanın Amacı}

$\mathrm{Bu}$ çalışmanın amac1, Türkiye'de üniversite eğitimi gören yabanc1 uyruklu öğrencilerinin yazma kaygılarını cinsiyet, uyruk, bildiği diğer yabancı diller, Türkçeyi öğrenme amacl, Türkçeyi kullanma düzeyi, Türkçe öğrenme süresi, alfabe farkl, kitap okuma alışkanlığl, ögrenim gördüğü fakültelyüksekokul gibi değişkenler ışı̆̆ında ele almak ve bu değişkenler ile öğrencilerin yazma kaygıları arasında anlamlı farklılığın olup olmadığını tespite çalışmaktır.

Bu bağlamda araştırmanın temel amacına ulaşmak için aşağıdaki alt problemlere cevap aranmıştır:

1. Yabancı uyruklu öğrencilerin yazma kaygıları ne düzeydedir?

2. Yabancı uyruklu öğrencilerin yazma kaygıları arasında cinsiyete göre anlamlı farklılık var mıdır?

3. Yabancı uyruklu öğrencilerin yazma kaygıları arasında uyruklarına göre anlamlı farklılık var midır?

4. Yabancı uyruklu öğrencilerin yazma kaygıları arasında öğrenim gördüğü fakülte ve yüksekokula göre anlamlı farklılık var mıdır?

5. Yabancı uyruklu öğrencilerin yazma kaygıları arasında bildikleri yabancı dillere göre anlamlı farklılık var midır?

6. Yabancı uyruklu öğrencilerin yazma kaygıları arasında Türkçeyi öğrenme sürelerine göre anlamlı farklılık var mıdır? 
7. Yabancı uyruklu öğrencilerin yazma kaygıları arasında okuma alışkanlıklarına göre anlamlı farklılık var midir?

8. Yabancı uyruklu öğrencilerin yazma kaygıları arasında ülkelerinde kullandıkları alfabelere göre anlamlı farklılık var mıdır?

\section{YÖNTEM}

\section{Araştırma Modeli}

Eğitim amaçlı Türkiye’ye gelen yabancı uyruklu öğrencilerin Türkçe yazma kaygılarını tespit etmeyi ve çeşitli değişkenlere göre değerlendirmeyi amaçlayan bu araştırmada "betimleyici tarama modeli" kullanılmıştır. Tarama modeli, geçmişte ya da hâlen var olan bir durumu olduğu gibi betimlemeyi amaçlamaktadır (Karasar, 2006: 77).

\section{Örneklem}

Yabancı uyruklu öğrencilerin yazma kaygılarını çeşitli değişkenleri dikkate alarak belirlemeyi amaçlayan bu araştırmanın evrenini 2014-2015 eğitim-öğretim yılında Türkiye'de öğrenim gören yabancı uyruklu öğrenciler oluşturmaktadır. Araştırma evrenini temsil edecek özellikte örneklem ise tesadüfi örnekleme yöntemi ile tespit edilmiştir. Örneklem, 2014-2015 eğitim-öğretim yılında Giresun Üniversitesinin farklı bölümlerinde öğrenim gören 172 yabancı uyruklu öğrenciden oluşmaktadır. Örneklemde yer alan yabancı uyruklu öğrencilere ait bilgiler aşağıdaki şekildedir:

Tablo 1: Öğrencilerin cinsiyet bilgileri

\begin{tabular}{ccc}
\hline & Frekans & Yüzde \\
\hline Bay & 112 & $\% 65,1$ \\
\hline Bayan & 60 & $\% 34,9$ \\
\hline Toplam & & 172 \\
\hline
\end{tabular}

Araştırmanın örnekleminde yer alan yabancı uyruklu öğrencilerin 60'ı bayan, 112'si baylardan oluşmaktadır.

Tablo 2: Öğrencilerin uyrukları

\begin{tabular}{ccc}
\hline & Frekans & Yüzde (\%) \\
\hline Azerbaycan & 125 & 72,7 \\
\hline Kazakistan & 20 & 11,6 \\
\hline Türkmenistan & 4 & 2,3 \\
\hline Burundi & 5 & 2,9 \\
\hline Gürcistan & 1 & 0,6 \\
\hline Afganistan & 5 & 2,9 \\
\cline { 2 - 3 } & \multicolumn{2}{c}{} \\
\hline Uluslararası Türkçe Edebiyat Kültür Eğitim Dergisi Sayl: 4/2 2015 s. 748-769, TÜRKIYYE
\end{tabular}




\begin{tabular}{ccc}
\hline Filistin & 1 & 0,6 \\
\hline Rusya & 3 & 1,7 \\
\hline Kirgizistan & 2 & 1,2 \\
\hline Bosna Hersek & 1 & 0,6 \\
\hline Almanya & 3 & 1,7 \\
\hline Hollanda & 2 & 1,2 \\
\hline Toplam & & 172 \\
\hline
\end{tabular}

Araştırmanın örnekleminde yer alan öğrencilerin \% 72,7'si Azerbaycan uyruklu olup geriye kalan \% 27,3'ü ise Kazakistan, Türkmenistan, Burundi, Rusya, Almanya, Kırgızistan, Filistin, Bosna-Hersek, Hollanda, Gürcistan ve Afganistan uyrukludur.

Araştırmanın örnekleminde yer alan öğrencilere Türkçeyi öğrenme amaçları (Eğitim, $\dot{I}_{s ̧ \text {, }}$ Turizm şeklinde) sorulmuş, örneklemdeki tüm öğrenciler Eğitim amacıyla Türkçe öğrendiklerini belirtmişlerdir.

Tablo 3: Öğrencilerin Türkçeyi öğrenme süreleri

\begin{tabular}{ccc}
\hline & Frekans & Yüzde (\%) \\
\hline 6-12 ay & 26 & 15,1 \\
\hline $12-24$ ay & 131 & 76,2 \\
\hline 24 aydan fazla & 15 & 8,7 \\
\hline Toplam & & \\
\hline
\end{tabular}

Araştırmanın örnekleminde yer alan öğrencilerin Türkçeyi öğrenme süreleri hakkında verdikleri cevaplar doğrultusunda; öğrencilerin \% 76,2'sinin 12-24 ay, \% 15,1'inin 6-12 ay ve $\% 8,7^{\prime} \operatorname{sinin} 24$ aydan fazla süre Türkçe öğrenmeye dair geçmişe sahip olduğu tespit edilmiştir.

Tablo 4: Öğrencilerin öğrenim gördükleri fakülte ve yüksekokullar

\begin{tabular}{ccc}
\hline & Frekans & Yüzde (\%) \\
\hline Eğitim & 23 & 13,4 \\
\hline İktisadi ve İdari Bilimler & 105 & 61,0 \\
\hline Mühendislik & 4 & 2,3 \\
\hline Fen-Edebiyat & 7 & 4,1 \\
\hline İletişim & 13 & 7,6 \\
\hline İslami İlimler & 5 & 2,9 \\
\hline Meslek Yüksekokulu & 15 & 8,7 \\
\hline Toplam & &
\end{tabular}

Araştırmaya katılan yabanc1 uyruklu öğrencilerin öğrenim gördükleri fakülte ve yüksekokullar incelendiğinde; \% 61'inin İktisadi ve İdari Bilimler Fakültesinde, \% 13,4'ünün Eğitim Fakültesinde, \% 8,7'sinin Meslek Yüksekokulunda, \% 7,6'sının İletişim Fakültesinde, \% 
4,1'inin Fen-Edebiyat Fakültesinde, \% 2,9'unun İslami İlimler Fakültesinde ve \% 2,3'ünün Mühendislik Fakültesinde öğrenim gördükleri tespit edilmiştir.

Araştırmaya katılan öğrencilere Türkçe düzeyleri (Temel, Orta, Ileri) sorulmuş, tümünün Orta seviyede oldukları tespit edilmiştir.

Tablo 5: Öğrencilerin bildikleri yabancı diller

\begin{tabular}{ccc}
\hline & Bir yabancı dil & İki ve daha fazla \\
\hline Frekans & Yüzde (\%) \\
\hline İngilizce & 72 & 41,9 \\
\hline Rusça & 46 & 26,7 \\
\hline Diğer & 4 & 2,3 \\
\hline Yab. Dil Bilmeyen & 50 & 29,1 \\
\hline Toplam & & \\
\hline
\end{tabular}

Araştırmaya katılan öğrencilerin Türkçe dışında bildikleri yabancı diller incelendiğinde; bir yabancı dil bilenlerin \% 41,9'unun İngilizce, \% 26,7'sinin Rusça, \% 2,3'ünün diğer dilleri (Arapça, Almanca) bildikleri ve \% 29,1'inin ise hiç yabancı dil bilmedikleri tespit edilmiştir. İki yabancı dil bilenlerin ise \% 19,2'sinin Rusça, \% 8,7'sinin diğer dilleri (Arapça, Almanca) bildikleri görülmüştür.

Tablo 6: Öğrencilerin ülkelerinde kullandıkları alfabeler

\begin{tabular}{ccc}
\hline & Frekans & Yüzde \\
\hline Kiril & 33 & 19,2 \\
\hline Latin & 133 & 77,3 \\
\hline Arap & 5 & 2,9 \\
\hline Diğer & 1 &, 6 \\
\hline Toplam & & 172 \\
\hline
\end{tabular}

Araştırmaya katılan öğrencilerin ülkelerinde kullandıkları alfabeler incelendiğinde; \% 19,2'sinin ülkesinde Kiril, \% 77,3'ünün Latin, \% 2,9'unun Arap ve \% 0,6'sinın ülkesinde ise Gürcü alfabesinin kullanıldığı tespit edilmiştir.

Tablo 7: Öğrencilerin kitap okuma alışkanlıkları

\begin{tabular}{ccc}
\hline & Frekans & Yüzde (\%) \\
\hline Haftada bir kitap & 11 & 6,4 \\
\hline Ayda bir kitap & 51 & 29,7 \\
\hline $\begin{array}{c}\text { Ayda birden fazla kitap } \\
\text { Yilda ve daha fazla sürede bir } \\
\text { kitap }\end{array}$ & 15 & 8,7 \\
\hline Toplam & 95 & 55,2 \\
\hline
\end{tabular}


Araştırmaya katılan öğrencilerin kitap okuma alışkanlıkları incelendiğinde \% 29,7'sinin ayda bir kitap, \%8,7'sinin ayda birden fazla kitap, \% 6,4'ünün haftada bir kitap okuduğu buna karşın \% 55,2'sinin yılda ve daha fazla sürede ancak bir kitap okuduğu tespit edilmiştir.

\section{Verilerin Toplanması}

Yabancı uyruklu öğrencilerin yazma kaygılarının çeşitli değişkenler çerçevesinde ölçülmeye çalışıldığı bu araştırmada veriler, araştırmacılar tarafından ilgili alanyazından hareketle geliştirilen 4'lü likert tipi Yazma Kaygısı Ölçeği'nden yararlanılarak elde edilmiştir. Yazma Kaygısı Ölçeği, 4) Her Zaman 3) Çoğunlukla 2) Ara sıra 1) Hiçbir Zaman aralığında ölçeklendirilmiştir.

Yazma Kaygısı Ölçeği, iki bölümden oluşmuştur: İlk bölüm kişisel bilgi formu (Yaş, cinsiyet, uyruk, bildiği yabancı diller, Türkçeyi öğrenme süresi ve amacl, Türkçeyi bilme seviyesi, anne-baba meslekleri, kitap okuma alışkanlarl, ögrenim gördüğ̈̈ fakültelyüksekokul), ikinci bölüm ise yazma kaygısını ölçen maddelerden oluşmaktadır. Yazma kaygısını ölçmeye yönelik ölçeğin hazırlık sürecine, alanyazındaki araştırmalardan yola çıkarak 29 maddelik havuz oluşturulması ile başlanmıştır. Taslak ölçek, kapsam geçerliliği açısından 4 Türkçe eğitimi akademisyenince ve 3 TÖMER okutmanınca incelenmiştir. Giresun Üniversitesi TÖMER Türkçe hazırlık kurslarında öğrenim gören 50 öğrenci üzerinde araştırma öncesi ön uygulamaya tabi tutulmuştur. Ön uygulamada elde edilen veriler 1şığında güvenirlik analizi yapılmıştır. Elde edilen verilerden hareketle ölçeğin Cronbach Alpha değeri 0.86 olarak tespit edilmiştir. Kapsam geçerliği ve güvenirlik analizi sonucunda ölçekten, kapsam dişı olan 2, düşük güvenirliğe sahip 1 madde çıkartılmış ve ölçeğe 26 maddelik son hâli verilmiştir. 26 maddelik kaygı ölçeği, alanyazındaki ölçme araçları ve uzman görüşü doğrultusunda, Birey Odaklı Kaygl, Çevre Odaklı Kaygı, Yazılı Anlatım Kurallarına Bă̆lı Kaygı, Yazı Aracına ve Biçime Bağlı Kaygı ve Yazma Psikolojisine Bağlı Kaygı şeklinde 5 alt boyuta ayrılmıştır. Ölçekteki maddeler, yönlendirme ihtimaline karşı alt boyutlara göre gruplandırılmadan ve rastgele yerleştirilerek öğrencilere sunulmuştur.

Yazma Kaygısı Ölçeği, araştırmanın örneklemini oluşturan 172 yabancı uyruklu öğrenciye araştırmacılar tarafından elden ulaştırılmış ve toplanmıştır.

\section{Veri Analizi}

Araştırmada elde edilen veriler, araştırma amacı ve alt problemler doğrultusunda, SPSS 16.0 programı kullanılarak çözümlenmiş; bulgular, tablolar hâlinde sunulmuş ve yorumlanmıştır. 
Verilerin toplanmasında kullanılan kaygı ölçeğinde yer alan aralık değerlerini derecelendirmek için aralık hesaplama yoluna gidilmiştir. Bu doğrultuda ölçekte yer alan aralık değerlerine $n-1 / n$ aralık genişliği formülü uygulanmıştır. Formül ile hesaplanan aralık genişliği dikkate alınarak (her aralıkta 0.74 puan olacak şekilde) dört eşit parçaya bölünerek her seçeneğe karşılık gelen puan aralıkları aşağıdaki şekilde belirlenmiştir:

Tablo 8: Ölçek Puan Aralıkları

\begin{tabular}{ccc}
\hline Seçenekler & Verilen Puanlar & Puan Aralı̆̆ \\
\hline Hiçbir Zaman & 1 & $1,00-1,74$ \\
\hline Ara sıra & 2 & $1,75-2,49$ \\
\hline Çoğunlukla & 3 & $2,50-3,24$ \\
\hline Her Zaman & 4 & $3,25-4.00$ \\
\hline
\end{tabular}

Elde edilen veriler 1şığında, örneklemin hepsinde aynı özellik söz konusu olduğundan Türkçe öğrenme amacı değişkeninin yazma kaygı ortalamalarına etkisi analizi edilmemiştir. Elde edilen verilerin analizinde, yazma kaygısı ortalamalarının çözümlenmesinde aritmetik ortalama, cinsiyet değişkeni test etmek için $\boldsymbol{t}$ testi, diğer değişkenlerin etkisini test etmek için tek yönlü varyans analizi (ANOVA) kullanılmıştır. Elde edilen verilerin analizinde anlamlılık düzeyi $0,05(\mathrm{p}<0,05)$ olarak uygulanmıştır.

\section{BULGULAR}

Tablo 9: Yabancı uyruklu öğrencilerin yazma kaygılarına ilişkin değerler

\begin{tabular}{|c|c|c|c|c|c|}
\hline Kaygı Boyutları & $\mathbf{N}$ & $\bar{x}$ & Standart Sapma & Minimum & Maksimum \\
\hline Birey Odakl1 Kayg1 & \multirow{6}{*}{172} & 2,2849 & 60476 & 1,00 & 3,50 \\
\hline Çevre Odaklı Kayg 1 & & 2,7301 & ,39644 & 1,86 & 3,86 \\
\hline $\begin{array}{c}\text { Yazılı Anlatım Kurallarına } \\
\text { Bağlı Kaygı }\end{array}$ & & 2,3065 & ,44769 & 1,29 & 3,71 \\
\hline $\begin{array}{l}\text { Yazı Aracına ve Biçime } \\
\text { Bağlı Kaygı }\end{array}$ & & 2,5465 & ,52567 & 1,50 & 4,00 \\
\hline $\begin{array}{c}\text { Yazma Psikolojisine Bağlı } \\
\text { Kayg1 }\end{array}$ & & 2,5436 & ,39965 & 1,33 & 3,67 \\
\hline Genel Ortalama & & 2,5105 & ,29798 & 1,73 & 3,58 \\
\hline
\end{tabular}

Yabancı uyruklu öğrencilerin Türkçe yazma kaygılarına yönelik veriler değerlendirildiğinde; örneklemdeki öğrencilerin Birey Odaklı Kaygı düzeylerinin 2,28; Çevre Odaklı Kaygı düzeylerinin 2,73; Yazılı Anlatım Kurallarına Bağlı Kaygı düzeylerinin 2,30; Yazı Aracına ve Biçimine Bağlı Kaygl düzeylerinin 2,54; Yazma Psikolojisine Bağlı Kaygl düzeylerinin ise 2,53 düzeyinde olduğu bununla birlikte genel kayg1 düzeylerinin 2,51 düzeyinde olduğu tespit edilmiştir. 
Tablo 10: Yabancı uyruklu öğrencilerin yazma kaygısı ortalamaları ve değerleri

\begin{tabular}{|c|c|c|c|c|}
\hline $\begin{array}{l}\text { Kaygı } \\
\text { Boyutları }\end{array}$ & & 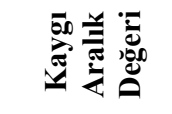 & $\bar{x}$ & $\begin{array}{l}\text { Standart } \\
\text { Sapma }\end{array}$ \\
\hline \multirow{2}{*}{ 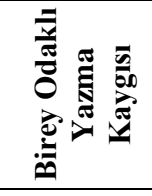 } & $\begin{array}{l}\text { Düşüncelerimi yazmaya başladığımda aklımdan her şey } \\
\text { silinmiş gibi olur. }\end{array}$ & Ara sira & 1,78 & 0,801 \\
\hline & $\begin{array}{l}\text { Duygu ve düşüncelerimi yazarak ifade etmek bana } \\
\text { zaman kaybı gibi gelir. }\end{array}$ & Çoğunlukla & 2,79 & 0,867 \\
\hline \multirow{7}{*}{ 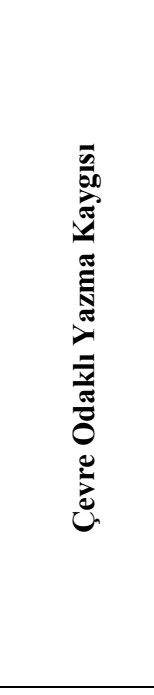 } & $\begin{array}{l}\text { Oluşturduğum yazılı metni arkadaşlarıma göstermekten } \\
\text { kaçınırım. }\end{array}$ & Ara sira & 2,25 & 1,038 \\
\hline & $\begin{array}{l}\text { Yazdıklarımın değerlendirileceğini düşünmek beni } \\
\text { endişelendirir. }\end{array}$ & Ara sira & 2,33 & 1,155 \\
\hline & $\begin{array}{l}\text { Yazdıklarımın (mektup, mesaj, ödev, günlük vb.) } \\
\text { değerlendirilmesi beni kaygılandırır. }\end{array}$ & Ara sira & 2,04 & 1,081 \\
\hline & $\begin{array}{l}\text { Temel ihtiyaçlarımı gidermede konuşmaya daha çok } \\
\text { ihtiyaç duyuyor olmam, yazma alışkanlığımı geri plana } \\
\text { iter, beni endişelendirir. }\end{array}$ & Her Zaman & 3,42 & 0,733 \\
\hline & $\begin{array}{l}\text { Yazı güzelliğinden çok yazdıklarımın önemsenmesi } \\
\text { beni rahatlatır. }\end{array}$ & Çoğunlukla & 2,92 & 1,079 \\
\hline & $\begin{array}{l}\text { Türkiyeli arkadaşlarımın bana göre çok iyi yazıyor } \\
\text { olması bende moral bozukluğuna strese sebep olur. }\end{array}$ & Çoğunlukla & 3,23 & 0,950 \\
\hline & $\begin{array}{l}\text { İnsanların yazdıklarımı beğenmiş gibi yaptıklarını } \\
\text { düşünür, sinirlenirim. }\end{array}$ & Çoğunlukla & 2,93 & 0,869 \\
\hline \multirow{7}{*}{ 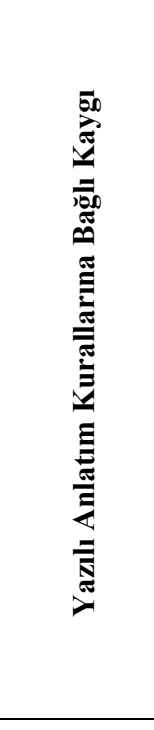 } & $\begin{array}{l}\text { Yazma etkinliklerinde, düşüncelerimi düzenlerken ve } \\
\text { mantık sırasına koyarken tedirgin olurum. }\end{array}$ & Ara sira & 1,83 & 0,817 \\
\hline & $\begin{array}{l}\text { Yazarken noktalama hatalarını sıkça yapmaktan } \\
\text { korkarım. }\end{array}$ & Ara sira & 1,94 & 0,931 \\
\hline & $\begin{array}{l}\begin{array}{l}\text { Yazarken dil bilgisi hataları yapmaktan endişe } \\
\text { duyarım. }\end{array} \\
\end{array}$ & Her Zaman & 3,31 & 0,813 \\
\hline & $\begin{array}{l}\text { Yazılacak konunun sinırlı tutulması heyecanlanmama } \\
\text { ve bildiklerimi unutmama sebep olur. }\end{array}$ & Ara sira & 2,03 & 0,855 \\
\hline & $\begin{array}{l}\text { Yazarken kelimelerin tamamını Türkçe olarak yazmam } \\
\text { gerektiği düşüncesi yazma etkinliğine tam olarak } \\
\text { odaklanmamı engeller. }\end{array}$ & Her Zaman & 3,27 & 0,801 \\
\hline & $\begin{array}{l}\text { İyi bir yazılı metin oluşturamayacağım düşüncesi strese } \\
\text { girmeme sebep olur. }\end{array}$ & Ara sira & 1,91 & 0,8788 \\
\hline & $\begin{array}{l}\text { Resmi kurumlara yazılı olarak yapacağım başvurularda } \\
\text { (pasaport, vize, mektup, dilekçe vb.) kendimi yetersiz } \\
\text { hissediyor ve paniklemeye başlarım. }\end{array}$ & Ara sira & 1,86 & 0,856 \\
\hline \multirow{4}{*}{ 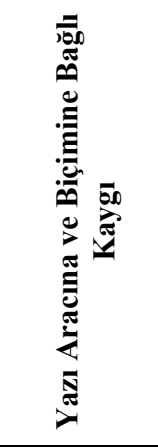 } & $\begin{array}{l}\text { El yazısı yazma alışkanlığımdan dolayı değerlendirme } \\
\text { aşamasında sıkıntı yaşayacağım düşüncesi beni } \\
\text { yazmaya karşı isteksizliğe iter. }\end{array}$ & Ara sira & 1,77 & 0,886 \\
\hline & $\begin{array}{l}\text { Türkçe kurslarında sıklıkla yaptığımız } \\
\text { egzersizleri sayesinde yazarken kendimi } \\
\text { hissederim. }\end{array}$ & Çoğunlukla & 3,04 & 1,092 \\
\hline & $\begin{array}{l}\text { Elektronik araçlarla yazdıklarımı paylaşmak ve kâğıda } \\
\text { geçirmek beni tedirgin eder. }\end{array}$ & Her Zaman & 3,27 & 0,857 \\
\hline & $\begin{array}{l}\text { Yazılı çalışma yapılan derslerde, yazılı çalsşma } \\
\text { yapılmayan derslere göre daha çok tedirgin olurum. }\end{array}$ & Ara sıra & 2,11 & 1,006 \\
\hline
\end{tabular}




\begin{tabular}{|c|c|c|c|}
\hline Yazdıklarımın yeterliliğinden şüphe duyarım. & Çoğunlukla & 2,89 & 0,968 \\
\hline $\begin{array}{l}\begin{array}{l}\text { Düşüncelerimi kâğıt } \\
\text { kaygılandırır. }\end{array} \\
\end{array}$ & Her Zaman & 3,03 & 0,787 \\
\hline $\begin{array}{l}\text { Düşüncelerimi hiçbir zaman açık bir şekilde yazıya } \\
\text { dökemeyeceğimi düşünür ve tedirgin olurum. }\end{array}$ & Ara sira & 2,29 & 0,994 \\
\hline $\begin{array}{l}\text { Diğer arkadaşlarımdan daha kötü yazdığımı düşünmek } \\
\text { beni kaygılandırır. }\end{array}$ & Ara sira & 2,05 & 1,149 \\
\hline $\begin{array}{l}\text { Yazdıklarımın sınıf ortamında okunacağını düşününce } \\
\text { kalbim çarpmaya başlar. }\end{array}$ & Her Zaman & 3,26 & 0,759 \\
\hline $\begin{array}{l}\text { Yazma çalışmaları yapılacağı zaman o derslere } \\
\text { girmekten kaçınırım. }\end{array}$ & Hiçbir Zaman & 1,45 & 0,782 \\
\hline
\end{tabular}

Yabancı uyruklu öğrencilerin Türkçe yazma kaygılarının boyutlara göre incelenmesi sonucunda;

Birey Odaklı Yazma Kaygısı boyutu açısından, öğrencilerin Ara Sıra $(1,77)$ ve Çoğunlukla $(2,79)$ aralığında yazılı anlatım esnasında kaygı duydukları,

Çevre Odaklı Yazma Kaygısı boyutu açısından, öğrencilerin Ara Sıra (2,03-2,33), Çoğunlukla $(2,91-3,22)$ ve Her Zaman $(3,41)$ aralığında yazılı anlatım esnasında kaygı duydukları,

Yazılı Anlatım Kurallarına Bağlı Kaygı boyutu açısından, Ara Sira (1,83-2,02) ve Her Zaman (3,26-3,31) aralığında yazılı anlatım esnasında kaygı duydukları,

Yazı Aracına ve Biçimine Bağlı Kaygı boyutu açısından, Ara Sıra (1,77-2,11), Çoğunlukla $(3,04)$ ve Her Zaman $(3,26)$ aralığında yazılı anlatım esnasında kaygı duydukları,

Yazma Psikolojisine Bağlı Kaygı boyutu açısından, Hiçbir Zaman (1,45), Ara Sira $(2,04-2,28)$, Çoğunlukla $(2,89-3,03)$ ve Her Zaman $(3,32)$ aralığında yazılı anlatım esnasında kaygı duydukları görülmektedir.

Tablo 11: Yabancı uyruklu öğrencilerin yazma kaygılarının cinsiyet değişkenine göre analizi

\begin{tabular}{cccccc}
\hline Cinsiyet & $\mathbf{N}$ & $\bar{x}$ & Standart Sapma & t & $\begin{array}{c}\text { Anlamlılık } \\
\text { Seviyesi }\end{array}$ \\
\hline Bay & 112 & 2,5014 &, 31429 & $-0,480$ & 0,548 \\
\hline Bayan & 60 & 2,5276 &, 26657 & & \\
\hline
\end{tabular}

Yabancı uyruklu öğrencilerin Türkçe yazma kaygılarına yönelik veriler incelendiğinde, bay ve bayan öğrencilerin yazılı anlatım sürecinde duydukları kaygının birbirine yakın olduğu ve anlamlı bir farkl11ı göstermediği belirlenmiştir ( $t=0,480$; sig.0,548).

Tablo 12: Yabancı uyruklu öğrencilerin yazma kaygılarının uyruk değişkenine göre analizi

\begin{tabular}{cccccc}
\hline Uyruk & $\mathbf{N}$ & $\bar{C}$ & $\begin{array}{c}\text { Standart } \\
\text { Sapma }\end{array}$ & $\mathbf{F}^{(12,159)}$ & $\begin{array}{c}\text { Anlamlılık } \\
\text { Seviyesi }\end{array}$ \\
\cline { 1 - 3 } Azerbaycan & 125 & 2,4314 & 0,22377 & & \multirow{2}{*}{7,760} \\
Kazakistan & 20 & 2,5154 & 0,21771 & 0,000 \\
\hline Türkmenistan & 4 & 2,6635 & 0,61968 & \\
\hline
\end{tabular}




\begin{tabular}{cccc}
\hline Burundi & 5 & 2,8615 & 0,47465 \\
\hline Gürcistan & 1 & 2,8077 & - \\
\hline Afganistan & 5 & 2,7431 & 0,20243 \\
\hline Filistin & 1 & 3,0385 & - \\
\hline Rusya & 3 & 2,9744 & 0,15544 \\
\hline Kirgizistan & 2 & 2,6846 & - \\
\hline Bosna Hersek & 1 & 2,8077 & - \\
\hline Almanya & 3 & 3,0000 & 0,24019 \\
\hline Hollanda & 2 & 3,4231 & 0,21757 \\
\hline
\end{tabular}

Levenetest: (3,176; sig; 0,057)

Yabancı uyruklu öğrencilerin Türkçe yazma kaygılarının uyruklarına göre analizi sonucunda; yazılı anlatım sürecinde duydukları kaygı düzeyleri arasında anlamlı farklılık olduğu belirlenmiştir $(F=7,760$,sig.0,00). Bulgulardan hareketle, en düşük yazma kaygısına Azerbaycan uyruklu öğrencilerin en yüksek kaygıya ise Filistin, Almanya ve Hollanda uyruklu öğrencilerin sahip oldukları görülmektedir. Dolayısıyla Asya ve Avrupa uyruklu öğrenciler ile Türk soylu yabancı uyruklu öğrencilerin Türkiye Türkçesi yazma kaygılarının Türk soylu öğrenciler lehine anlamlı farklılık arz ettiği ortaya çıkmaktadır.

Tablo 13: Yabancı uyruklu öğrencilerin yazma kaygılarının öğrenim gördükleri fakülte/yüksekokul değişkenine göre analizi

\begin{tabular}{|c|c|c|c|c|c|}
\hline & $\mathbf{N}$ & $\overline{2}$ & $\begin{array}{c}\text { Standart } \\
\text { Sapma }\end{array}$ & $\mathbf{F}^{(4,167)}$ & $\begin{array}{c}\text { Anlamlılık } \\
\text { Seviyesi }\end{array}$ \\
\hline Eğitim Fakültesi & 23 & 2,4649 & 0,24350 & \multirow{5}{*}{0,877} & \multirow{5}{*}{0,479} \\
\hline $\begin{array}{c}\text { İktisadi İdari } \\
\text { Bilimler } \\
\text { Fakültesi }\end{array}$ & 105 & 2,5172 & 0,30972 & & \\
\hline $\begin{array}{l}\text { Mühendislik } \\
\text { Fakültesi }\end{array}$ & 4 & 2,2788 & 0,38381 & & \\
\hline $\begin{array}{c}\text { Fen Edebiyat } \\
\text { Fakültesi }\end{array}$ & 7 & 2,5659 & 0,29519 & & \\
\hline Diğer & 33 & 2,5373 & 0,28645 & & \\
\hline
\end{tabular}

Türkiye'ye yükseköğrenim için gelmiş yabancı uyruklu öğrencilerin Türkçe yazma kaygılarının öğrenim gördükleri fakülte/yüksekokul değişkenine göre analizi sonucunda, en düşük kaygıya Mühendislik Fakültesi öğrencilerinin en yüksek kaygıya ise Fen Edebiyat Fakültesi öğrencilerinin sahip olduğu belirlenmiştir. Yabanc1 uyruklu öğrencilerin Türkçe yazma kaygılarının öğrenim gördükleri fakülte/yüksekokul türüne göre anlamlı farklılık arz etmediği de tespit edilmiştir ( $F=0,877$, sig.0,479). 
Tablo 14: Yabancı uyruklu öğrencilerin yazma kaygılarının Türkçeyi öğrenme sürelerine göre analizi

\begin{tabular}{cccccc}
\hline & $\mathbf{N}$ & $\bar{L}$ & Standart Sapma & $\mathbf{F}^{(2,169)}$ & $\begin{array}{c}\text { Anlamlılık } \\
\text { Seviyesi }\end{array}$ \\
\hline 6-12 Ay & 26 & 2,4201 &, 21591 & 4,386 & 0,14 \\
\hline 12-24 Ay & 131 & 2,5464 &, 29507 & & \\
\hline 24 Aydan Fazla & 15 & 2,3538 &, 37324 & & \\
\hline (Levene test; 0,737, sig.0,480) & & &
\end{tabular}

Yabancı uyruklu öğrencilerin Türkçe yazma kaygılarının Türkçe öğrenme sürelerine göre analizi sonucunda, 6-12 ay, 12-24 ay ve 24 ay ve daha fazla süredir Türkçe öğrenenlerin yazma kaygılarının değişiklik gösterdiği belirlenmiştir. Türkçe yazma kaygısının 12-24 aydır Türkçe öğrenenlerde daha yüksek olduğu; bununla birlikte Türkçe öğrenme süresi açısından yazma kaygıları arasında anlamlı farklılık olmadığı tespit edilmiştir $(F=4,386$, sig.0,14).

Tablo 15: Yabancı uyruklu öğrencilerin yazma kaygılarının bildikleri diğer yabancı dillere göre analizi

\begin{tabular}{|c|c|c|c|c|c|}
\hline & $\mathbf{N}$ & $\overline{14}$ & $\begin{array}{c}\text { Standart } \\
\text { Sapma }\end{array}$ & $\mathbf{F}^{(3,168)}$ & $\begin{array}{c}\text { Anlamlılık } \\
\text { Seviyesi }\end{array}$ \\
\hline İngilizce & 72 & 2,4772 & ,28498 & \multirow{4}{*}{2,170} & \multirow{4}{*}{0,093} \\
\hline Rusça & 46 & 2,4640 & ,23469 & & \\
\hline $\begin{array}{c}\text { Diğer (Almanca, } \\
\text { Arapça) }\end{array}$ & 4 & 2,5673 & 20919 & & \\
\hline $\begin{array}{l}\text { Yabancı Dil } \\
\text { Bilmeyenler }\end{array}$ & 50 & 2,5969 & ,35763 & & \\
\hline
\end{tabular}

Yabancı uyruklu öğrencilerin Türkçe yazma kaygılarının yabancı dil bilme durumlarına ve bildikleri yabancı dillere göre analizi sonucunda, yabancı dil bilen öğrencilerin yazma kaygılarının bilmeyenlere göre daha düşük olduğu, en düşük yazma kaygısının Rusçayı yabancı dil olarak bilenlerde görüldüğü ve yabancı dil değişkeni açısından yazma kaygıları üzerinde anlamlı bir farklılık bulunmadığı belirlenmiştir $(F=2,170$, sig.0,093). Bu bulgu, yabancı uyruklu öğrencilerin yabancı dil bilmesinin Türkçeyi yabancı dil olarak öğrenmelerine katk1 sağlayacağını göstermektedir.

Tablo 16: Yabancı uyruklu öğrencilerin yazma kaygılarının kitap okuma alışkanlıklarına göre analizi

\begin{tabular}{|c|c|c|c|c|c|}
\hline & $\mathbf{N}$ & $\bar{L}$ & Standart Sapma & $\mathbf{F}^{(3,168)}$ & $\begin{array}{c}\text { Anlamlılık } \\
\text { Seviyesi }\end{array}$ \\
\hline $\begin{array}{c}\text { Yılda ve daha çok sürede } \\
\text { bir kitap }\end{array}$ & 96 & 2,655 & ,29701 & \multirow{4}{*}{8,072} & \multirow{4}{*}{0,000} \\
\hline Ayda bir kitap & 16 & 2,536 & ,23394 & & \\
\hline Ayda birden fazla kitap & 49 & 2,525 &, 27852 & & \\
\hline Haftada bir kitap & 11 & 2,108 & ,18591 & & \\
\hline
\end{tabular}


Yabancı uyruklu öğrencilerin Türkçe yazma kaygıları ile kitap okuma alışkanlıkları arasındaki ilişkiye yönelik analiz sonucunda, kitap okuma alışkanlığı yüksek olan öğrencilerde yazma kaygısının düşük olduğu tespit edilmiştir. Kitap okuma alışkanlığı zayıf olan yabancı uyruklu öğrencilerle kitap okuyan yabancı uyruklu öğrenciler arasında Türkçe yazma kaygısı açısından anlamlı bir farklılık olduğu görülmüştür $(F=8,072$, sig.0,00). Örneklemdeki yabancı uyruklu öğrencilerin çoğunluğunun yılda ve daha fazla sürede bir kitap okuduğu düşünüldüğünde, yabancı öğrencilerin Türkçe yazılı anlama ve anlatma becerisine ulaşmak için zorlanacakları ve kaygı etkeni ile yazma başarılarının düşeceği söylenebilir.

Tablo 17: Yabancı uyruklu öğrencilerin yazma kaygılarının ülkelerinde kullanılan alfabelere göre analizi

\begin{tabular}{|c|c|c|c|c|c|}
\hline & $\mathbf{N}$ & $\bar{L}$ & $\begin{array}{c}\text { Standart } \\
\text { Sapma }\end{array}$ & $\mathbf{F}^{(3,168)}$ & $\begin{array}{c}\text { Anlamlılık } \\
\text { Seviyesi }\end{array}$ \\
\hline Kiril & 33 & 2,6632 & ,34776 & \multirow{4}{*}{8,863} & \multirow{4}{*}{0,000} \\
\hline Latin & 133 & 2,4552 & ,25767 & & \\
\hline Arap & 5 & 2,9000 & ,34465 & & \\
\hline Diğer & 1 & 2,8846 & . & & \\
\hline
\end{tabular}

Yabancı uyruklu öğrencilerin Türkçe yazma kaygılarının ülkelerinde kullandıkları alfabelere göre analizi sonucunda, farklı alfabelere göre Türkçe yazma kaygılarının değişiklik gösterdiği tespit edilmiştir. Türkiye Türkçesinde olduğu gibi Latin alfabesi kullanılan ülkelerden gelen öğrencilerin yazma kaygılarının düşük olduğu, dolayısıyla alfabenin yazma kaygısında belirleyici olduğu görülmüştür. Yabancı uyruklu öğrencilerden yazma kaygısının en yüksek olduğu öğrencilerin Arap alfabesinin kullanıldığı ülkelerden geldiği belirlenmiştir. Ülkelerinde Latin, Kiril, Arap ve diğer (Gürcü) alfabeleri kullanan yabancı uyruklu öğrencilerin Türkçe yazma kaygılarının Latin alfabesi kullananlar lehine anlamlı farklılık gösterdiği ortaya çıkmıştır $(F=8,863$, sig.0,00). Hedef dil olarak Türkçeyi öğrenen öğrencilerin çoğunluğunun (133) ana dilini / ülkesinin dilini de Türkiye'de olduğu gibi Latin alfabesiyle kullandığg bu açıdan yabancı dil olarak Türkçe öğrenme ve kullanmada bir kolaylığın olduğu görülmektedir.

\section{Sonuç ve Tartışma}

Yazma ve yazılı anlatım becerisi gerek ana dili gerekse yabancı dil öğrenme sürecinde, anlama ve anlatmanın tam manasıyla sağlanabilmesinde büyük işleve sahiptir. $\mathrm{Bu}$ nedenle yazma becerisi kazandırılırken güdü, güven ve eleştirinin önemi dikkate alınmalıdır. Bireyin kendini yazılı olarak ifade ederken kendine güvenmeme, yanlış yapma, yetersizlik ve değerlendirilme korkusu yaşaması düşüncelerini yazıya yeterince aktaramamasını beraberinde getirebilir, bu durumda yazmaktan kaçınma ve yazma becerilerine ket vurma ortaya çıkabilir. 
Sarason (1988: 3) endişe ve kaygının, öğrencinin performansında çok büyük bir etkiye sahip olduğunu ve değerlendirme sürecine çok fazla odaklanan öğrencilerin, çok yüksek kaygı taşıdıklarını öne sürmektedir. Bu biçimde yazma becerisine engel olabilecek durumlardan olan yazma kayg1s1, "bireyi yazma becerisinin bütün düzeylerinde etkileyebilir ve bireyin yazmaktan kaçınmasına sebep olabilir" (Corbett-Whittier, 2004: 88). Aynı şekilde alanyazında yapılan çalışmalarda da, "endişeli öğrencilerin düşük özyeterlik gösterme eğiliminde oldukları ve böylece kendilerini hedef dilde daha düşük seviyede" yazılı olarak ifade edebildikleri yönünde benzer sonuçlara ulaşı1mıştır (Jones, 2008; Shang, 2012). "Yazmaya karşı geliştirilen bir tepki olan yazma kaygısı; üzüntü, kızgınlık, korku şeklinde duygusal olarak ya da çeşitli kramplar ve terleme şeklinde de fiziksel olarak kendini gösterir" (Poff, 2004: 168). Yazılı anlatım faaliyetlerine karşı ortaya çıkan bu tepki günlük iletişimde yazarak mesaj iletirken, bir deste yazma ödevini, etkinliğini ya da sınavı çözerken veyahut yazarak hazırlanacak bir performans etkinliğinde ortaya çıkabilir. Dil becerilerini öğrenmede yaşanabilecek kaygı durumları bilhassa yabancı dil öğretimi sürecinde yeni bir dili, kısa sürede yeni bir kültür ile edinirken kendini çok kolay ve açık biçimde gösterebilir. Bu doğrultuda, Türkçeyi yabancı dil olarak öğrenen öğrencilerin yazma kaygılarının tespit edilmesi ve çeşitti değişkenler açısından incelenmesi amacıyla yapılan araştırma bulgularından hareketle aşağıdaki sonuçlara ulaşılmıştır:

Yabancı uyruklu öğrencilerin Türkçe yazma kaygılarına yönelik bulgulara göre; örneklemdeki öğrencilerin Birey Odaklı Kaygı düzeylerinin Ara Sıra; Çevre Odaklı Kaygı düzeylerinin Çoğunlukla; Yazılı Anlatım Kurallarına Bă̆lı Kaygı düzeylerinin Ara Sıra; Yazı Aracına ve Biçimine Bă̆lı Kaygı düzeylerinin Çoğunlukla; Yazma Psikolojisine Bă̆lı Kaygı düzeylerinin ise Çoğunlukla aralığında olduğu belirlenmiştir. Buna ek olarak, yabancı uyruklu öğrencilerin Türkçe yazarken Çoğunlukla yazma kaygısı yaşadıkları tespit edilmiştir.

Yabancı uyruklu öğrencilerin yazma kaygılarının cinsiyet açısından farklılık göstermediğine dair bulgu, bayan ve bay öğrencilerin yazarken birbirine yakın kayg1 duyduklarını ancak farklı kültürel özelliklere sahip olmalarından dolayı Türkçeyi öğrenirken ve kullanırken birbirlerinden farklı düzeyde beceri ve tutum sergilediklerini ortaya koymaktadır. Örneklemdeki öğrencilerin uyruklarına göre yazma kaygılarının farklılık gösterdiği ve en düşük kaygıya Azerbaycan uyruklu öğrencilerin en yüksek kaygıya ise Filistin, Almanya ve Hollandalı öğrencilerin sahip olduğu görülmüştür. Ayrıca, yabancı uyruklu öğrencilerin yazma kaygılarının öğrenim gördükleri fakülte/yüksekokullara, Türkçe öğrenme sürelerine ve yabancı dil bilme durumlarına göre farklılık göstermediği belirlenmiştir.

Yabancı uyruklu öğrencilerin ülkelerinde kullandıkları alfabelere göre Türkçe yazma kaygılarının Latin alfabesi kullananlar lehine farklılık gösterdiği ve en yüksek kaygıya Arap 
alfabesi kullananların sahip olduğu tespit edilmiştir. Bu bulgu, ana dillerini öğrendikleri ve kullandıkları alfabelerin kullanımına dair özelliklerin farklı olmasından dolayı Latin alfabesinin dışındaki alfabeleri kullanan öğrencilerin Türkçe yazarken yeterli performans sergileyemediklerini göstermektedir. Yabancı uyruklu öğrencilerin yazma kaygılarının kitap okuma alışkanlıklarına göre farklılık arz ettiği, okuma alışkanlığ zayıf olan öğrencilerin yazma kaygılarının ise yüksek düzeyde olduğu görülmüştür. Kitap okuma alışkanlığının hem ana dilinde hem de yabancı dil öğrenmedeki başarıyı etkilediğini gösteren bulgu, okuma alışkanlığının bilgi edinmede ve paylaşmada ne kadar etkili olduğunu desteklemektedir. Bu sonuç, yazabilmek için okumanın hayati ve zorunlu olmasının yabancı dil öğrenmede de geçerli olduğunu ortaya koymaktadır.

Yazılı anlatım başarısını ve gelişimi etkileyen önemli unsurlardan biri olan yazma kaygısı ile ilgili alanyazında birçok araştırma bulunmaktadır (Daly ve Miller, 1975, Martinez, Kock ve Cass, 2011; Yaman, 2010; Zorbaz, 2010). Ayrıca yabancı dil öğretimi sürecinde yazma kaygısının önemli bir özellik olduğuna dair de araştırmalar mevcuttur (Rogers, 1989; Aydın, 2001). Araştırma bulguları, ilgili alanyazındaki çalışmaların bulgu ve değerlendirmelerini desteklemektedir. Bunlara ek olarak, Türkçenin yabancı dil olarak öğretiminde, kaygı üzerine sadece konuşma kaygısını inceleyen araştırmaların alanyazında yer aldığı görülmektedir (Özdemir, 2012; Sallabaş, 2012; Melanlığlu ve Demir, 2013). Ancak Türkçeyi yabanc1 dil olarak öğrenen öğrencilerin Türkçe yazma kaygı durumlarını inceleyen araştırmalar yeterli değildir.

Araştırma bulgularından hareketle, Türkçeyi yabancı dil olarak öğrenen öğrencilerin yazarken çoğunlukla kaygılandıkları ve uyruklarına, ülkelerinde kullandıkları alfabelere, okuma alışkanlıklarına bağlı olarak kaygı düzeylerinin yükseldiği görülmektedir. Örneklemdeki yabancı uyruklu öğrencilerin Türkçeyi orta düzeyde öğrendikleri ve kullandıkları da düşünüldüğünde yazma kaygılarının bu seviyeyi yükseltmede engel teşkil edebileceği düşünülebilir. $\mathrm{Bu}$ nedenle, yazma kaygı düzeylerinin azaltılması ve ortadan kaldırılması için yabancı dil olarak Türkçe öğretimi sürecinde birtakım değişikliklere gidilmelidir. Örnek olarak aşağıdaki öneriler sunulabilir:

Yabancılara Türkçe öğretiminde yazma becerisinin hangi amaçlar çerçevesinde verileceği önceden belirlenmeli,

Türkçeyi yabancı dil olarak öğrenenlere yazma becerisi kazandırırken güdülenme ve ilgi düzeylerine dikkat edilmeli,

Yabancılara Türkçe öğretirken kullanılan destekleyici ders araç-gereçleri kolaydan zora doğru ve uygulamaya dönük olarak işe koşulmalı, 
Yabancılara Türkçe öğretirken yazma becerisi günlük yaşamdaki ihtiyaçlar dikkate alınarak öğretilmeli,

Yabancılara Türkçe öğretiminde yazılı anlatım becerisi kazandırmak için yetkin edebi metinler özenle seçilmeli,

Türkçe öğrenen yabancı uyruklu öğrenciler okuma konusunda teşvik edilmeli,

Yabancı uyruklu öğrencilere Türkçe yazma öğretiminde sınıf içi uygulamalar bilgisayar ve internet destekli araçlarla ders dişı ortamlara da yayılmalı,

Yabanc1 uyruklu öğrencilere Türkçe öğreten öğreticilere meslek öncesinde yeterli eğitim verilmeli ve mesleki yaşamda da bilgi ve becerilerini çağdaş gelişmelere göre destekleyecek hizmet içi seminerler düzenlenmeli,

Yabancı dil olarak Türkçe öğretiminde kaygının özel olarak da yazma kaygısının önemli bir etken olduğu kabul edilmeli, eğitim sürecinde dikkate alınmalı,

Yabancı dil olarak Türkçe öğretiminde kaygı üzerine durum tespiti, çözüm önerileri ve içerik oluşturmaya yönelik araştırmalar yapılmalıdır.

\section{Kaynaklar}

AKYOL, H. (2010). Türkçe Öğretim Yöntemleri. Ankara: Pegem Akademi Yayıncılık.

ALYILMAZ, C. (2010). Türkçe Öğretiminin Sorunları. Turkish Studies, 5(3), 728-749.

AYDIN, B. (2001). Konuşma ve Yazma Derslerinde Yabancı Dil Öğrenimindeki Kaygı Nedenleri. Doktora Tezi, Eskişehir: Anadolu Üniversitesi Yayınları.

AYDIN, S. ve ZENGIN, B. (2008). Yabancı Dil Öğreniminde Kaygı: Bir Literatür Özeti. Journal of Language and Linguistic Studies, 4(1), 81-94.

BAKIRCIOĞLU, R. (2012). Ansiklopedik Eğitim ve Psikoloji Sözlüğü. Ankara: Anı Yayınc1lı.

BOYLU, E. ve ÇANGAL, Ö. (2015). Yabancı Dil Olarak Türkçe Öğrenen Bosna-Hersekli Öğrencilerin Konuşma Kaygılarının Çeşitli Değişkenler Açısından İncelenmesi. Uluslararası Türkçe Edebiyat Kültür Ë̆itim (TEKE) Dergisi, 4(1), 349-368.

CARTER, C., BISHOP, J. ve KRAVITS, L. (2002). Key to Effective Learning. New Jersey: Printice Hall.

CORBETT-WHITTIER, C. (2004). Writing Apprehension in Adult College Undergraduates: Six Case Studies. University of Kansas. Unpublished PhD Thesis (UMI Number: 3185142).

ÇAKIR, İ. (2010). Yazma Becerisinin Kazanılması Yabancı Dil Öğretiminde Neden Zordur? Erciyes Üniversitesi Sosyal Bilimler Enstitüsü Dergisi, 28, 165-176.

DALY, J. and MILLER, M. (1975). The Empirical Development of an Instrument to Measure Writing apprehension. Research in The Teaching Of English, 12, 242-49.

DEMIREL, Ö. (2002). Türkçe Öğretimi. Ankara: Pegem Akademi Yayıncılık.

ER, O., BIÇCER, N. ve BOZKIRLI, K. Ç. (2012). Yabancılara Türkçe Öğretiminde Karşılaşılan Sorunların İlgili Alan Yazını Işı̆̆ında Değerlendirilmesi. Uluslararası Türkçe Edebiyat Kültür Eğitim (TEKE) Dergisi, 1(2), 51-69. 
GÖÇER, A. (2010). Türkçe Öğretiminde Yazma Eğitimi. Uluslararası Sosyal Araştırmalar Dergisi, 3(12), 178-195.

HARMER, J. (2004). Teach Writing. England: Longman.

HARMER, J. (2007). How to Teach English. England: Pearson Education Limited.

İŞERİ, K. ve ÜNAL, E. (2012). Türkçe Öğretmen Adaylarının Yazma Kaygı Durumlarının Çeşitli Değişkeler Açısından İncelenmesi. Mersin Üniversitesi Eğitim Fakültesi Dergisi, $8(2), 67-76$.

JONES, E. (2008). Predicting Performance in First-Semester College Basic Writers: Revisiting the Role of Self-Beliefs. Contemporary Educational Psychology, 33, 209-238.

KARASAR, N.(2006). Bilimsel Araştırma Yöntemi. Ankara: Nobel Yayın Dağıtım.

KARATAY, H. (2011). Süreç Temelli Yazma Modelleri: Planlı Yazma ve Değerlendirme (ed. Murat Özbay). Yazma Eğitimi. Ankara: Pegem Akademi Yayıncılık.

MARTINEZ, T., KOCK, N. ve CASS, J. (2011). Pain and Pleasure in Short Essay Writing: Factors Predicting University Students' Writing Anxiety and Writing Self-Efficaty. Journal of Adolescent \& Adult Literaty. International Reading Association. 54(5) 351360.

MELANLIOĞLU, D. ve DEMIR, T. (2013). Türkçe Öğrenen Yabancılar İçin Konuşma Kaygis1 Ölçeğinin Türkçe Formunun Geçerlik ve Güvenirlik Çalışması. The Journal of Academic Social Science Studies. 6(3), 389-404.

NUNAN, D. (2003). Practical English Language Teaching. USA: McGrawHill Publications.

ÖZBAY, M. ve ZORBAZ, K. Z. (2011). Daly-Miller'in Yazma Kaygısı Ölçeğinin Türkçeye Uyarlanmas1. Mustafa Kemal Üniversitesi Sosyal Bilimler Enstitüsü Dergisi, 8(16), 3348.

ÖZBAY, M., BAĞCI, H. ve UYAR, Y. (2008). Türkçe Öğretmeni Adaylarının Okuma Alışkanlığına Yönelik Tutumlarının Çeşitli Değişkenlere Göre Değerlendirilmesi. İnönü Üniversitesi Ë̆itim Fakültesi Dergisi, 9(15),117-136.

ÖZDEMIR, E. (2012). Türkçeyi Yabancı Dil Olarak Öğrenenlerin Konuşma Kaygılarının Kaynakları. Yayımlanmamış Yüksek Lisans Tezi, Ankara: Gazi Üniversitesi Eğitim Bilimleri Enstitüsü.

ÖZTÜRK, K. B. (2012). İlköğretim İkinci Kademe Öğrencilerinin Yazma Kaygılarının Çeşitli Değişkenler Açısından İncelenmesi. Ç.Ü. Sosyal Bilimler Enstitüsü Dergisi, 21, 2.

POFF, I. (2004). Regimentation: A Predictor of Writer's Block and Writing Apprehension. Unpublished PhD Thesis, University of Southern California (UMI Number: 3155461).

REEVES, L.L. (1997). Minimizing Writing Apprehension in The Learner-Centered Classroom. English Journal, 86(6), 38-45.

SALLABAŞ, M. E. (2012). Türkçeyi Yabancı Dil Olarak Öğrenenlerin Konuşma Kaygılarının Değerlendirilmesi. Turkish Studies, 7(3), 2199-2218.

SARASON, I. G. (1988). Anxiety, Self-preoccupation, andattention. Anxiety Research, 1, 3-7.

SCOVEL, T. (1978). The Effect of Affect on Foreign Language Learning: A Review of The Anxiety Research. Language Learning, 28(1), 129-141.

SHANG, H. F. (2012). The Relationship Between Writing Anxiety and EFL University Students' Writing Proficiency. Manuscript presented in the $19^{\text {th }}$ International Conference on Learning, London, UK. 
TİRYAKİ, N. E. (2013). Yabanc1 Dil Olarak Türkçe Öğretiminde Yazma Eğitimi. Ana Dili Eğitimi Dergisi, 1(1), 38-44.

TÜRK DİL KURUMU (TDK) (2005). Büyük Türkçe Sözlük. (10. Baskı) Ankara: TDK Yayınları.

UNGAN, S. (2007). Yazma Becerisinin Geliştirilmesi ve Önemi. Dumlupınar Üniversitesi Sosyal Bilimler Enstitüsü Dergisi, 23(2), 461-472.

WAY, D. P., JOINER E. G. ve SEAMAN, M. A. (2000). Writing in the Secondary Foreign Language Classroom: The Effects of Prompts and Tasks on Novice Learners of French. Modern Language Journal, 84(2), 155-281.

YALÇIN, G. Ü. (1997). Beyin-Dil İlişkisi ve Bunun Yazma Becerilerine Yansımaları. 4. Ulusal Eğitim Bilimleri Kongresi Bildirileri, s. 372-385, Eskişehir: Anadolu Üniversitesi.

YALÇIN, S. D. (1998). Yazma Eğitiminde Yeni Bir Araştırma Alanı: Yaratıcı Yazarlık, Türkçenin Öğretimi ve Eğitimi Sempozyum Bildiriler, s. 145-152, AÜ TÖMER Gaziantep Şubesi Yayını.

YAMAN, H. (2010). Türk Öğrencilerinin Yazma Kaygısı: Ölçek Geliştirme ve Çeşitli Değişkenler Açısından Yordama Çalışması. International Online Journal of Educational Sciences, 2(1), 267-289.

ZORBAZ, K. Z. (2010). İlköğretim Okulu Öğrencilerinin Yazma Kaygı ve Tutukluğunun Yazılı Anlatım Becerileriyle İlişkisi. Yayınlanmamış Doktora Tezi, Ankara: Gazi Üniversitesi Eğitim Bilimleri Enstitüsü. 